\title{
Ethnologies
}

\section{Intangible Culture on Inland Seas, from Hudson Bay to Canadian Heritage}

\section{Jennifer S.H. Brown}

Volume 36, numéro 1-2, 2014

Patrimoine culturel immatériel

Intangible Cultural Heritage

URI : https://id.erudit.org/iderudit/1037604ar

DOI : https://doi.org/10.7202/1037604ar

Aller au sommaire du numéro

Éditeur(s)

Association Canadienne d'Ethnologie et de Folklore

ISSN

1481-5974 (imprimé)

1708-0401 (numérique)

Découvrir la revue

Citer cet article

Brown, J. S. (2014). Intangible Culture on Inland Seas, from Hudson Bay to Canadian Heritage. Ethnologies, 36(1-2), 141-159.

https://doi.org/10.7202/1037604ar
Résumé de l'article

L'auteur de cet article examine la façon dont la Convention pour la sauvegarde du patrimoine culturel immatériel envisage la protection des langues autochtones et peut constituer une étude de cas des difficultés que présente la conservation de la langue cri au Canada. Pour les peuples autochtones, au Canada comme ailleurs, se pose la question de savoir qui parle au nom de qui ; nombre de membres de leurs groupes ne se reconnaissent pas toujours dans les principales organisations politiques qui les représentent auprès des gouvernements et qui sont reconnues par les instances gouvernementales; et l'on voit également se dresser d'autres barrières structurelles et logistiques. Cet article commence par présenter la richesse de l'histoire des Autochtones des environs de la baie d'Hudson telle qu'elle apparaît dans la langue et dans les histoires, avant de discuter des nombreuses difficultés auxquelles ont été confrontés un conteur cri de la baie d'Hudson, Louis Bird, et ses collaborateurs, lorsqu'ils travaillaient à un projet d'histoire orale financé par un organisme gouvernemental canadien qui avait ses propres paramètres et priorités.
Ce document est protégé par la loi sur le droit d'auteur. L'utilisation des services d’Érudit (y compris la reproduction) est assujettie à sa politique d'utilisation que vous pouvez consulter en ligne.

https://apropos.erudit.org/fr/usagers/politique-dutilisation/ 


\title{
Intangible Culture on Inland Seas, from Hudson Bay to Canadian Heritage
}

\author{
Jennifer S.H. Brown \\ University of Winnipeg
}

In October 2003, UNESCO adopted a Convention for the Safeguarding of Intangible Cultural Heritage. Its aim was to ensure "the viability of the intangible cultural heritage $(\mathrm{ICH})$, including the identification, documentation, research, preservation, protection, promotion, enhancement, transmission... as well as the revitalization of the various aspects of such heritage" (quoted in M.F. Brown, 2005: 47). The domains covered by the convention included "rituals, beliefs, customs, music, festivals, storytelling, cuisine, popular knowledge, and other living traditions of a people, often expressed through material objects and cultural landscapes" (Turgeon, 2006).

The UNESCO document of 2003 built upon and supplemented an earlier convention (1972), which was drafted to protect the world's natural and cultural heritage in its material forms-for example, monuments, buildings, sculpture, and archaeological sites. The 2003 convention went further, recognizing the "deep-seated interdependence" between the tangible and intangible and the importance of the living traditions linked to material forms of heritage (Phillips, 2006). Similar evolutions in thinking have occurred in recent times in heritage circles in various countries. In Canada, the Historic Sites and Monuments Board of Canada (HSMBC) has shifted its emphasis over the last two to three decades. Its focus used to be mainly on the mandate furnished by its name-commemorations of and protection for physical sites and monuments. In recent years, it has given increased attention to new categories of persons of historical significance, both women and men, and to members of previously overlooked ethnic and Aboriginal groups, also taking account of cultural landscapes and oral traditions as repositories of historical significance (although it has remained uncomfortable about how to weigh oral history). In the same period, the 
Department of Canadian Heritage also entered the field of intangible heritage, starting the new century with programs such as its Aboriginal Languages Initiative and Canadian Culture Online. ${ }^{1}$

All these initiatives have lent support to many valuable projects and to critical heritage preservation work. Yet as Laurier Turgeon noted in his prospectus for the seminar series for which this paper was originally prepared, "The politics of intangible cultural heritage has in recent years stirred up lively discussion and debate in Canada, in the United States and in many other countries" (2006). ${ }^{2}$ Canada, the United States, Great Britain, and Australia are among the important nations that have not signed on to the convention. Heritage in its material forms can be contentious enough, as issues of prior and existing rights, title, and ownership stir ongoing conflict; witness the unending tensions between the British Museum and Greece over the Elgin Marbles. But international and national efforts to define and legislate the protection of intangible cultural heritage are also lightning rods for contention. Because ICH has to do with living traditions, both the people who carry those traditions and the researchers who work with them must deal with the international organizations, government departments, and other agencies that pursue these initiatives and make policies about them.

For Indigenous people, in Canada as elsewhere, questions also arise about who speaks for whom; many of their constituents may not identify with the major political organizations that represent their interests to governments and are recognized by government agencies; and other structural and logistical barriers also arise. This paper takes a look at the richness of Aboriginal history around Hudson Bay as held in language and stories- $\mathrm{ICH}$, and then discusses the many challenges that a Hudson Bay Cree storyteller, Louis Bird, and his collaborators faced in pursuing an oral history project funded by a Canadian governmental agency with its own parameters and priorities.

1. Until 1998, the Historic Sites and Monuments Board and its linked agency, Parks Canada, were under the Minister of Canadian Heritage. Then, in a governmental shift in 1998, both the board and Parks Canada were placed under Environment Canada; Parks reports to the Minister of the Environment, while the HSMBC advises the minister on historic designations (Scott Stephen, e-mail, 23 May 2014).

2. "The Politics of Intangible Cultural Heritage": seminar series held at the Weatherhead Center for International Affairs, Harvard University, spring 2006. 


\section{Touching the Intangible}

The etymology of the term, "intangible," points to some of the problems arising. In a literal reading of the word, intangible entities cannot be touched. Like spirits, souls, or sound waves, they may be materialized in some secondary form as pictographs commemorating visions, or as artists' images, or enacted by storytellers and vision keepers in song or ceremony, recorded, or written down or written about. But they are in motion, and may be variously claimed, transmitted (or not), appropriated, modified, diminished, enhanced, translated, and otherwise mediated. As Michael F. Brown points out in a recent article on intangible cultural property, such intangibles are also forms of information, and information "can reside in an infinite number of places simultaneously." The ease with which it travels, or what Brown calls its homelessness, "undermines the distinction between real and counterfeit, just as it weakens the bond that ties units of information together in meaningful systems." As a consequence, efforts to define, protect, and defend intangible culture run into what Brown calls "'heritage trouble' - that is, diffuse global anxiety about the movement of information among different cultures" (2005: 41-42).

The enthusiasm of various agencies to manage and protect $\mathrm{ICH}$ militates against confronting such ambiguous issues as these, however, as governmental entities organize and monopolize political space not only for worthy goals of preservation, but also to perpetuate their initiatives and agendas within the bureaucratic structures in which they must operate. And because of their power as sources of funds and legitimacy for heritage projects, whatever work goes forward is subject to their parameters and terms of reference. Scholars and communities working in such contexts quickly become aware of issues regarding power, control, and contesting priorities, goals, and budgeting priorities (and timelines), and of the extent to which knowledge and heritage itself are recast in the crucible of presentday politics.

It is possible, however, to accomplish a lot of good work outside the high-profile politics of intangible cultural heritage (PICH, to coin another acronym). Beneath the radar of $\mathrm{PICH}$, individuals and communities constantly generate, retrieve, and maintain intangible heritage through names and stories that they themselves tell and share. In turn, scholars, particularly in low-budget fields such as the humanities, commonly work with people and their history for decades, delving into sources that may be widely dispersed in different places and media, working through language, names, concepts, and other means to better understand the historical 
perspectives, world view, epistemology, and relationships of communities that are not well known in history books or on the world scene.

A look at some examples of names and naming, ethnic and geographical, among the Cree (Omushkego) people of Hudson Bay illustrates how intangible heritage endures at these lower and less visible levels. "ICH" is embedded in words that speak volumes if we listen closely. Hudson Bay is a tidal inland sea that also presents complex tides and cross-currents of history and heritage, Cree and other. It offers many vistas onto the past if we look carefully in all directions. Certainly there is always more information to be gathered, and entities such as Canadian Heritage have helped to support new initiatives. But we already have rich documentation, written, oral, and material, on the peoples of Hudson Bay. Many of the informational resources already at hand have not been well studied or synthesized, and top-down bureaucratic superstructures do not necessarily offer good tools for exploring all that is already available. A great deal can be learned at ground level (or sea level on Hudson Bay), inexpensively, through close reading and listening, as the following discussion illustrates. But when the intangibles of people's heritage become vehicles for governmental policy and political agencies with interests of their own, new and complex issues arise.

\section{Omushkegowak and English in Hudson Bay: Old Words and New}

Cree-European interactions began just over four centuries ago on Hudson Bay. We can trace some of those relations and their legacies through words and stories, both English and Cree, and French to a lesser extent. On Hudson Bay, as elsewhere, words, stories, and documents tell us much about how Aboriginal people named and asserted their own identities, and in contrast, how they identified and related to the strangers whom they met as the English and French newcomers arrived. Hudson Bay Cree people or Omushkegowak (people of the muskeg), and Europeans constructed their own cultural landscapes in different ways that are revealed through names and stories.

The original Algonquian inhabitants of the region arrived perhaps five or six thousand years ago, after the glacial retreats of the last Ice Age, as demonstrated by archaeological findings in some sectors of the Hudson Bay Lowlands. Near the Bay, heavy erosion along the rivers complicates reconstruction of settlement history, but recent studies have indicated that people have lived and traveled along these waterways for 1500 to 2000 
years, hunting lowland caribou and other game, trapping small animals, fishing, and harvesting the vast flocks of migratory birds that passed along the shores in spring and fall (Lytwyn, 2002: chapter 2).

Written sources for the region begin in the 1600s, first with Europeans searching for the Northwest PassageChina, and later with the founding of the Hudson's Bay Company (HBC) in 1670. The documentary record thereafter becomes quite massive, although produced, of course, by outsiders for their own purposes. The Hudson's Bay Company Archives, housed in the Archives of Manitoba, Winnipeg, hold remarkable quantities of journals, correspondence, accounts, maps, and other documentation and richly reward those who would search for intangible heritage in materialized written form. Complementing these archives and the academic research of Lytwyn and others are the rich story traditions and histories of the Omushkego people themselves. Much of this heritage has begun to be recorded in tangible forms by various parties. The work of Cree storyteller Louis Bird and his collaborators $(2005,2007)$ has been very productive, and a website, www.ourvoices.ca, which offers many of his stories, was created with major support from the Department of Canadian Heritage, of which I will say more later.

When King Charles II chartered the Hudson's Bay Company, he conferred a trade monopoly and various responsibilities upon a select group of "Adventurers" governed by his cousin Prince Rupert, of royalist military fame. They were to conduct their enterprise in what they called Rupert's Land, "one of our colonyes or plantacions in America," as the Charter expressed it, a region that Prince Rupert and the other early proprietors in fact never visited. The Charter defined the territory as consisting of the lands whose waters flowed into Hudson Bay. Its signers could not know that this watershed covered almost the upper third of North America. Nor could they grasp the nature of the climate, which in the grip of the Little Ice Age of the 1600s, was rather colder than it is now.

The Cree of the Hudson Bay lowlands were adapted to long, cold winters and a mobile hunting economy based on relatively few hardy species of animals and plants. The HBC English quickly learned that they needed the Cree as hunters, fur trappers and trade partners, and needed the women's skills at gathering country foods and making snowshoes, leather clothing, and moccasins. In Hudson Bay, the Indians were essential; they were not in the way or competing for land as in more southern climes. And many of them became relatives and descendants of Scots and Englishmen over the 200-year history of Rupert's Land from 1670 to 1870, when it 
was annexed to Canada. There are deep historical reasons why so many Cree families today go by the names of Spence, Flett, Harper, Sinclair, Sutherland, Linklater, and the like. Even when Englishmen and Cree became kin, however, northern communities remained separate. The Cree assimilated many descendants of fur traders, but they also remained distinct, and resided in their own First Nations communities across the Hudson Bay Lowlands. In turn, many other traders' descendants passed into mainstream society and have recently ventured to rediscover their Aboriginal ancestry and connections. ${ }^{3}$

\section{The Naming of People}

Names tell us much about relationships, social distance, and zones of silence and communication over time. They are among the most powerful symbolic manifestations of intangible cultural heritage. They also surface quite often in early records, as newcomers felt compelled to name the places and people they "discovered," and as Aboriginal people gave them names that the newcomers sometimes recorded but rarely understood.

The earliest European/Aboriginal encounters in Hudson Bay (and everywhere else) are usually described as first contacts. I would represent those moments, however, as "illusions of contact." Contact (derived, like "tangible," from the Latin verb, tangere, to touch, and its participle, tactus), implies that people were really (tangibly) in touch. It connotes communication and acquaintance. But groups could be aware of one another, seeing, watching, hearing, and talking, without achieving real communication. They often thought they knew more than they did, as they tried to make sense of strangers and their ways and fit them into their own frames of reference. Issues of language and translation were huge, and yet have often been obscured as first efforts at conversations were retrospectively constructed or inferred. Yet with collaborative detective work, we can trace how strangers on both sides drew upon their own frames of reference to create words and categories that they applied to others. The new terms then got entrenched, transformed, and sometimes misunderstood as they passed among various parties and sometimes lost their roots, receiving new etymologies.

A few examples of Cree, and in some instances, Ojibwe terms used for outsiders help us to follow these processes. Each word tells or hints at a story

3. Many families descended from fur traders and First Nations have extensively researched their dual ancestry in recent years; see for example, What Lies behind the Picture? A Personal Journey into Cree Ancestry (2006), by Vernon R. Wishart. 
about how people learned about one another and what they learned. Some are third-party terms; that is, they arose from one group asking another about still other folk: "Who are they?" Of course, the other folk replied with their own outsider's term. Then there are terms associated with places where the strangers were first encountered, and those associations can be remarkably durable. Third, some names evoked material-culture associations, novel structures or artifacts associated with the strangers. (It is interesting that Aboriginal terms for other groups seldom refer to "racial" features such as skin color or "blood.")

A Cree-English dictionary that is a major resource for these studies (Faries and Watkins, 1938) has greatly aided my exploration of these topics and supplies several examples of intriguing words. One instance is the Cree term, 'akuyasew,' which the authors define as 'Englishman', adding, "The word is obtained from Akwayasew, 'he lands sailing'; the idea is that he comes from across the sea" (1938: 235). I was struck by how the poetical ring of the term glossed over reality; early Englishmen often "landed sailing" because they ran aground on the huge tidal mudflats along the shores of Hudson Bay. Indeed, an old story tells of how Cree people rescued the first strangers by helping to get their ship afloat at high tide (Bird, 2005: 157160). The term evoked strong images.

Then, however, I asked a linguist, David Pentland, about these words. He provided a caution about drawing associations between two words that look similar, and came up with an even more interesting explanation. The words that Faries and Watkins saw as related have distinct roots. 'Akwayasew' indeed means, 'he is blown ashore,' or 'beached by the wind.' But 'akuyasew,' meaning "Englishman," comes from the French language, and old French at that; it derives, in fact, not from 'anglais' but from its older form, 'anglois.' The term has cognates in other Algonquian languages: 'zhaaganaash' in Ojibwe, and 'aklasiyew' in Mi'kmaq (Pentland, e-mail, 24 March 2006). It must go back to the 1600 s when various Algonquian people started asking the French, who these other strangers were whom they saw arriving in eastern and southern James Bay. In reply, the French identified them as "les anglois," their term for the English who were building posts at the mouth of the Rupert River and elsewhere in the 1670s and 1680s.

David Pentland also helped me decipher another word. This one refers to French or French "canadiens." In telling an old Ojibwe story from northeastern Manitoba, Charlie George Owen of Pauingassi First Nation used the term, 'waabitigweyaa,' in reference to a European "who found the Anishinaabeg first" (Brown and Roulette, 2005). The Cree cognate, 
'wapistikwayaw,' exists on James Bay, in reference to French-speaking Oblate missionaries (Ellis, 1995: 248-249, 545). Both terms signify, "it is a narrows in a river": they are old words describing the location of Quebec near the mouth of the St. Lawrence River where it narrows. The name, Quebec, itself comes from a different Mi'kmaq root, 'kepe:k,' which means about the same thing (Pentland, e-mail, 29 March 2006). In sum, Algonquian names marking the place where the French established their first permanent settlement have endured for four centuries and spread across thousands of kilometers, in tandem with early Algonquian exposure to carriers of French identity and language. The name indeed conveys the fact that the French "found the Anishinaabeg first."

My third example is a James Bay Cree word for Englishman, 'wemistikosiw.' Its underlying meaning is "one who has a wooden boat," referring to the novel appearance of wooden sailing ships on Hudson Bay (Pentland, 1982: 106). The word encodes an image and object that made an enormous impression on first being sighted, and this term too, along with stories about these ships and their people, has endured among Cree speakers across four centuries. To gloss the term simply as "white man" loses this insight. An interesting secondary term also grew out of this word. As Hudson's Bay Company traders and Cree women founded families, the Cree needed a new term to describe children whom the English often described as "halfbreeds" from about 1820 on, so Cree speakers added a suffix, -hkan, which is commonly added to words to signify something that is artificial or made up (compare 'ogimahkan' for 'treaty or Indian Affairs chief,' someone elected by outsiders' rules). The result was 'wemistikosihkan,' "not really a white man” (Long, 1985: 162, citing linguist C. Douglas Ellis), the Hudson Bay Cree term for people who became known in other contexts by terms such as Metis and mixed-blood.

Most English and French speakers who met Cree people never learned these Cree terms or what they meant. And the process has worked the other way too. In English and French, the generic term, "Cree" or Cris took hold in the 1800s, as outsiders realized that closely related dialects of this language were spoken over a vast area from eastern James Bay to the northern Plains. Linguists tell us that "Cree" is an abbreviation of an old Ojibwe term, which the French in the mid-1600s learned as 'Kilisteneaux' or 'Kiristineaux' when they asked some Ojibwe for the identity of a nonOjibwe group somewhere near James Bay (Pentland, 1981: 227). In recent times, some Cree speakers and others have interpreted 'Kiristeneaux' as a short form of "Christian," referring to Cree groups that were Christianized 
first. This etymology does not hold up, but it demonstrates that "Cree" is an outsider term, even if drawn from an Algonquian root.

\section{Naming Places}

Just as ethnic names are intangible expressions of how these early strangers viewed each other, so a study of Cree and English place names sheds light on their different views of and relationships to land. The English (like other Europeans) named places after individuals, often patrons and royalty. As noted, the name Rupert's Land evoked possession by a landlord who never visited his namesake territory. The names Hudson Bay and James Bay commemorated two other notables-sea captains who were looking for the Northwest Passage but ended up wintering in the Bay and never accomplished their aim. The English remembered Hudson mainly for his fate of being set adrift by a mutinous crew in the spring of 1611, having had only one Cree visitor during his sojourn. Captain Thomas James made a lesser mark on history by creating a map that named the area where he wintered as "James his Baye"; in 1633, the year after his return, he also published a vivid and much read book entitled in part, The Strange and Dangerous Voyage of Capt. Thomas James in his Intended Discovery of a North West Passage into the South Sea wherein the Miseries Indured, both Going, Wintering and Returning, and the Rarities Observ'd Philosophical, Mathematical and Natural are Related....

In English, Cree people speak of Hudson and James bays. But in their own language, Cree never named places after individuals, and they exercised restraint in the use of personal names; kinship terms were preferred in social interaction. Cree place names were and are descriptive and concrete, often with stories attached. They point to key features that alert travelers about what to expect. Hence the Cree name for Hudson and James bays describes them together under one term, Win-ni-peg, "dirty water." As Omushkego elder Louis Bird explains, the water is salty and undrinkable, and an old story about the Giant Skunk recounts how it got that way (Bird, 2005: 69-78).

Other Cree names around Hudson Bay follow the same pattern, in contrast to the European names conspicuously entrenched on maps. In 1631, when Captain James passed the cape marking the west side of the entrance to James Bay, he named it Cape Henrietta Maria, after the queen of King Charles I whose patronage he cultivated (his ship also bore her name). Omushkego Cree, when speaking Cree, call that point of land, "Kini-ki-moo-sha-wow," which signifies a "barren, treeless headland," and say 
this was where they first heard the sound of guns as European ships fired at each other (possibly the rival English captains Thomas James and Luke Fox exchanging salutes on 29 August 1631). On the west side of Hudson Bay, James named a river with a large estuary the (New) Severn because it reminded him of the Severn River in his hometown of Bristol, which also had that feature. The Cree name concretely describes the estuary itself: Wa-sha-hoe means "the bay within the bay" (Bird, 2005: 138, 29). I have elaborated elsewhere on these verbal disjunctions between Cree and English with regard to places, also drawing attention to Cree versus English names for $\mathrm{HBC}$ posts (Brown, 2007).

\section{Double Mistaken Identity}

These examples suggest the extent to which English and Cree people each made their own observations, taking their values and worldviews as given and assimilating the new things they saw into their own frames of reference. Even as they traded and communicated, sometimes intimately, they rarely grasped the different perceptual universe in which their new familiars lived. James Lockhart, historian of the Nahuas (Aztecs) of Mexico after the Spanish conquest, has written about the ways that the Nahuas and Spanish understood each other (or not), and some of his points seem relevant here. As he observes, "each society/culture approached the other in a similar fashion, manifesting relatively little interest in the other side's internal structure, apparently expecting it in some way to mirror its own. The unspoken assumption of sameness showed itself above all in the way each used its own categories in interpreting cultural phenomena of the other. At the root of cultural interaction... was a process I have called Double Mistaken Identity, whereby each side takes it that a given form or concept is essentially one already known to it... and hardly takes cognizance of the other side's interpretation" (1992: 445).

Similarly, when Cree people encountered Englishmen and their carpentered ships and buildings, they naturalized or assimilated them into their own language in terms that they understood, just as the English applied their own terms to the people of Hudson Bay (Thomas James used 'Savages'; later HBC men used 'Indians'). As to places, while the Cree maintained their names in their language; the English attached their own to many of the same places. English-speakers gave little or no sign of exploring Cree names as ways of viewing or relating to the land, if indeed they learned the names in Cree. In turn, Cree people began to use English place names when speaking to Anglophones, but they were not in a position to grasp 
their origins or their significance for the English speakers, and had no reason to find them relevant. Some English names never registered with Cree people; the concept of Rupert's Land had no significance to most of them until recently. As legal claims and political questions have arisen, however, concerning, for example, Canada's assumption of responsibilities to Aboriginal people at the time of the Rupert's Land transfer to Canada in 1870, the implications of an ancient HBC charter and of its cancellation have assumed new relevance (Mushkegowuk Council, 2003).

\section{Doing History, Negotiating Heritage}

The exploring of language, words, and stories for the "ICH" embodied in them takes time, thought, and building of relationships among informed Aboriginal people and scholars. But they are richly productive for understanding the intangibles of Aboriginal and northern history, and various colleagues and I have worked to support deeper oral and documentary study in these areas. Some years ago, while based in the department of history at the University of Winnipeg, I began to explore possibilities with an anthropologist, George Fulford, who had done fieldwork on the western shore of Hudson Bay in the 1990s. He was working with a remarkable bilingual Omushkego (Cree) historian, Louis Bird, from Peawanuck, Ontario, who had begun in the 1970s to record, on cassette tapes, the stories of his family and community. Through a major grant from the Social Science and Humanities Research Council of Canada, we secured funds to assemble a research team. Louis came to Winnipeg for a time, and we began transcribing and doing background research on his stories, working towards the goal of preserving them and making them available for younger generations.

The grant was helpful in that it brought Louis Bird to our students and classes, initiated some research projects with him, and made his work better known. It was wonderful to be able to talk with him about the stories and history, language, translation issues, and many other things. But the work moved more slowly than planned. For many reasons both external and internal to the project, only a small portion of the 200-300 hours of tapes was transcribed. The focus was on the English stories; the Cree tapes were scarcely touched. A major problem was that Louis was the only available expert in his dialect of Cree. Meanwhile the collection kept growing, as he recorded more stories in English. The project team was to work together with Louis to word-process the transcriptions, but when Louis came to Winnipeg he was just beginning to use a computer. 
A further challenge was that Louis understandably wanted to register the Cree transcriptions in the syllabic writing system that he had learned from his earliest years. The syllabics, developed by a Methodist missionary in the region in the 1840s and picked up by Anglicans and Oblates, had proved easy for Cree speakers to learn, and they spread rapidly, offering an indigenous literacy used mainly for hymns and scriptures, but for other writings too. But as most younger people have not learned syllabics, they have become more esoteric, a kind of code, yet also a significant badge of identity and statement of language survival. Specialists had developed various computer fonts for keyboarding syllabic texts by 2002, but no single standard had found general acceptance. And for Cree transcription, no one could be found who combined all the needed skills, in speaking the correct dialect of Cree, in writing syllabics, and in computer proficiency.

When the first grant ended in 2002, we looked for more comprehensive funding on a large scale, to preserve and transcribe the entire collection and digitize the fragile cassette tapes onto CDs. Thus began our experience with the federal Department of Canadian Heritage, and specifically its Canadian Culture Online Branch. The CCO Branch was developing digital and Internet programs with a mandate "to bring our country's cultural content to Canadians"; they aimed "to foster dialogue between our diverse communities and promote our shared values and history" and to "enable Canadians...to participate and learn about our country's rich heritage, arts and culture." 4

At the University of Winnipeg, George Fulford undertook the arduous task of applying to the CCO Partnerships Fund, which was set up to assist non-profit, private, and public organizations and institutions "to connect all Canadians with the riches of Canada's heritage by making Canadian cultural collections... available via the Internet in both official languages." The Partnerships Fund aimed to support "projects for the development of online content" which would "provide a meaningful and seamless access to content that helps deepen an understanding of Canada and its rich diversity" in four areas: contemporary culture, Aboriginal culture [singular], Francophone community content, and cultural diversity. ${ }^{5}$ The funding formula was generous; a multiplier of four was applied to matching funds, greatly enhancing the limited funds that we ourselves raised. But the timing was dreadful. Delays in the processing of the grant and late arrival of funds

4. The quoted text came from the Department of Canadian Heritage website, www. pch.gc.ca/progs/pcce-ccop/about_e.cfm but the page is no longer available.

5. Department of Canadian Heritage website, "Partnerships Fund." Again the website text, still available in 2006, has since disappeared. 
left us with only four months, from January 2003 to the end of the fiscal year with a small extension into April, in the midst of an academic term in which the faculty involved were teaching their regular loads and student transcribers (hired on very short notice) were in the midst of courses, to do work that had been planned for a time frame of eight months to a year.

In spite of the conditions, a remarkable amount was accomplished. The major goal that Canadian Culture Online required us to fulfill was to set up a website for the stories; that was done, and about 80 of Louis Bird's English-language stories were made available at www.ourvoices.ca. The English and Cree tapes were all enhanced and copied onto CDs. The great majority of the English tapes were transcribed, and that in turn later made possible the book, Telling our Stories (Bird, 2005), and a second book of Louis' stories that appeared in 2007. 6 The great gap was in the Cree. Lack of time and qualified personnel meant that only one Cree story tape got transcribed into syllabics and placed on the website; and as Louis saw the Cree material fall behind and get sidetracked, his frustration grew, as did ours.

I can't review here all the logistical, operational, and bureaucratic difficulties the project faced, or the technical challenges of setting up, on short notice, sophisticated equipment and a website that required highly specialized, expensive experts who were only sporadically available. But part of the trouble was that we got enmeshed in PICH, the politics of intangible cultural heritage. Louis Bird tells old hunting stories about what he calls "funneling caribou," building fences to steer herds of woodland caribou to a narrow opening where they can be captured. Scholars and Native storytellers and historians like Louis Bird may wish that they could subsist on their own like the caribou, and follow their own paths and callings. But they and we are funneled too, harvested as it were, for the purposes of others. In order to secure the funds for Louis Bird's story work, which cried out to be done, we had to meet complex application requirements, build a website, line up specialized equipment and personnel, seek matching funds, publicize the project and produce immediate "deliverables." As a subtext, we were asked to assimilate the language and goals of Canadian Heritage, celebrating a great Canadian narrative of rich diversity and multiculturalism, while coping with a federal agency's hugely complex budgeting process and two separate audits.

6. Work on these books was supported not by Canadian Heritage but mainly through my Canada Research Chair in Aboriginal Peoples in an Urban and Regional Context, 2004 and following, which provided the time and funding that such projects need (they cannot be done within a bureaucrat's fiscal year). 
At least, since we were dealing with Aboriginal cultural materials, we were not required to do it all in French as well. But in no way did we have the resources, skills, or time to do the Cree language materials, and when it came down to the end, that was what Louis Bird wanted most. He had watched his language dying around him, even among his own grandchildren (twenty-five as of 2003). Canadian Heritage also insisted, of course, that there be open access to the website material. Louis remained the copyright holder and permissions for any further use were to come from him, but he and some of us were rather ill at ease with that provision, knowing how the Internet is used-raising the specter of the homelessness of information and the "heritage trouble" cited earlier by Michael F. Brown (2005). However, accepting the commitment to produce an open website was the only way to get the funds for the tapes to be enhanced, digitized, and transcribed so that they would be preserved on line and accessible for books and other projects too.

In the following year, we had hopes that a new Canadian Heritage program could help with Louis' Cree stories; an "Aboriginal Languages Initiative" (ALI) was announced with much fanfare. But its funds proved to be steered through political channels. Three national Aboriginal organizations, the Assembly of First Nations, the Metis National Council, and Inuit Tapiriit Kanatami, were the parties designated to apply for these Canadian Heritage funds, which they in turn were to deliver to "eligible recipients." These recipients "include[d] existing national and/ or regional Aboriginal representative and service delivery organizations such as Aboriginal communities/First Nations, Aboriginal governments or institutions, cultural education centres and Aboriginal Friendship Centres"; individuals were excluded. ${ }^{7}$ But Louis Bird always worked on his own. His community's chief and council belonged to other families than his, and some of them viewed him with suspicion, thinking he would enrich himself by getting external funds for his stories (he assuredly did not). We have here another sort of funneling, from the top down through certain approved and powerful chains of influence that exclude those persons who are not linked to them. Possibly some Cree speakers will have begun, or will begin to work with Louis' Cree tapes and CDs. Some hard work, partial funding, and technology saved them as of 2003, but all such reservoirs of knowledge

7 The page containing these passages is no longer available; the Aboriginal Languages Initiative website itself was last modified in June 2011. Janet Blake observes, regarding $\mathrm{ICH}$, that "there is always the potential for conflict between the needs of the group and those of the individuals within it," and further that individuals may not identify with the groups purporting to represent them, raising the issue of individual versus collective rights (Blake, 2009: 54). 
are vulnerable, and their means of support temporary. ${ }^{8}$ The Aboriginal Languages Initiative itself seems to have disappeared.

\section{Intangibles and Imponderables}

The aims of scholars, whether Aboriginal or non-Aboriginal, are congruent only to a limited extent with those of entities such as Canadian Heritage (or internationally, with UNESCO's Convention for the Safeguarding of the Intangible Cultural Heritage); the match is an awkward one at best. Governmental agencies involved with heritage, tangible and intangible, work in the present for national goals, drawing constructions of the past into encompassing narratives that serve current purposes. Scholars of history and culture are more interested in achieving the deepest understandings possible of names, words, stories, concepts, and lives, finding the best people and sources to help with the job. We need time and quiet places to think, listen, and work on the best means to learn, record and share the knowledge and insights that we gain. For me, Louis Bird's finest gifts came when he stayed in our home and we conversed endlessly on topics of mutual interest, and when he would rise early and sit talking quietly to his tape recorder in our second-floor sun room, making yet another recording of a story he wanted to tell or retell, and setting off another round of conversations and transcriptions. The most beneficial intellectual returns were the simplest and the least expensive.

As for the saving of the Cree language, that has to come from the heart, from the Aboriginal people and the communities themselves, with the help and energy of those individuals who in diminishing numbers are still fully fluent. The Canadian Heritage Aboriginal Languages Initiative program, channeled as it was through national political organizations, was unlikely to reach the experts who sit quietly at home or appear as token elders in so many meetings; and they in turn were unlikely to seek access to the program through the political channels required, and to complete all the forms, round up the needed references, and accept its other myriad demands. For all our modern technologies, real communication among the parties involved in our times has sometimes seemed as illusory and

8. Janet Blake comments that "it is only through its enactment by cultural practitioners that ICH has any current existence and by their active transmission that it can have any future existence" (2009: 65). Active transmission requires more than the creating of a website to be left under the passive guardianship of its host university, or the digitizing of Cree tapes onto CD-roms that sit in boxes; it requires focused follow-up far beyond the attention span of granting agencies with all their other political and national priorities. 
problematic as that of Henry Hudson with the lone Cree who came to visit his ship in James Bay in the spring of 1611 and never returned.

In the meantime, Canadian Heritage and other government agencies, federal and provincial, as they align with Aboriginal governments and organizations, have helped to construct a new "heritage," a generic Aboriginal culture, usually in the singular as on the $\mathrm{CH}$ website, which they all can use. An article by Jane K. Cowan sets this issue in a broader comparative frame, looking also at current debates about culture and rights in the context of multiculturalism and about "culture as an object of rights." The model of rights, she observes, has become "hegemonic in our times and imbued with an emancipatory aura." Yet it has "complex and contradictory implications for individuals and groups whose claims must be articulated within its terms" (2006: 9). She agrees with Elizabeth Povinelli, author of The Cunning of Recognition: Indigenous Alterities and the Making of Australian Multiculturalism, that "the recent revision of political and legal structures to recognize 'culture' and 'multiculturalism' has its own transformative effects, shaping and at times creating that which it purports merely to recognize." In the Australian context, Povinelli "shows 'Aboriginal culture' to be produced in the interaction between state agents, white Australian citizens, and Aboriginal citizens, all of whom are contesting memories of Australians' past and struggling to imagine and define its political future. Neither the perception of alterity nor the kind of culture founded on that perception are 'interior to the forms themselves'; rather...they are emergent in the sites of contact between them" (Cowan, 2006: 17-18). This outcome is more than a mixing of heritages, the patrimoines métissés of which Laurier Turgeon speaks in his important book on the subject (2003). It is something new, to be distinguished from the historical past, although it is of course making, performing, and becoming part of history itself. It has its parallels in Canada where the singularity of "Aboriginal culture" appears time and again in universalized public invocations of such metaphors as Turtle Island, Mother Earth, and the Medicine Wheel. ${ }^{9}$

9. Louis Bird pointed out at various times that the Iroquois and southern Ojibwe mythic image of the world on the back of a turtle has little resonance with people on Hudson Bay where there are no turtles. The other concepts also appear to have spread widely from south to north since the 1970s. As one of many examples, the $8^{\text {th }}$ Student Conference in Northern Studies, October 2007, sponsored by the Association of Canadian Universities for Northern Studies (ACUNS), which focuses on regions north of discontinuous permafrost, featured "breakout sessions grouped according to the four elements of the medicine wheel—air, fire, wind and water"; the omission of "earth" is perhaps a northern touch, but the medicine wheel concept is not indigenous to the North. 
So where do we go from here? In 1999, the distinguished anthropologist Clifford Geertz gave the annual Charles Homer Haskins Lecture at the American Council of Learned Societies meetings. He cited two basic lessons that he had learned in a lifetime of doing anthropology, and they seem useful in this context. First, "The study of other people's cultures... involves discovering who they think they are, what they think they are doing, and to what end they think they are doing it." Second, "To discover who people think they are, what they think they are doing, and to what end they think they are doing it, it is necessary to gain a working familiarity with the frames of meaning within which they enact their lives. This does not involve feeling anyone else's feelings, or thinking anyone else's thoughts, simple impossibilities. Nor does it involve going native, an impractical idea, inevitably bogus. It involves learning how, as a being from elsewhere with a world of one's own, to live with them" (1999: 11). His points sound simple, yet they pose complex challenges as we try to achieve understandings across cultural divides.

It is complicated enough to try to do good Aboriginal history and to pursue the interdisciplinary enterprise of ethnohistory along the tidal shores and shoals of Hudson Bay. Navigating the contemporary politics of intangible cultural heritage makes the exercise more complicated, for the politics themselves are intangibles. It may be helpful, then, to name them, to make them explicit, just as the old sailors took soundings and sightings to map a safe course among the shallows and sandbars of Hudson Bay. If researchers know what they are dealing with on all sides, it may help them find an anchorage for integrity and autonomy in a complicated world. 


\section{References}

Bird, Louis, 2005, Telling our Stories: Omushkego Legends and Histories from Hudson Bay. Jennifer S.H. Brown, Paul W. DePasquale and Mark F. Ruml (eds.). Peterborough: Broadview Press.

Bird, Louis, 2007, The Spirit Lives in the Mind: Omushkego Stories, Lives, and Dreams. Susan Gray (ed.). Montreal: McGill-Queen's University Press. Blake, Janet, 2009, “UNESCO's 2003 Convention on Intangible Cultural Heritage: the Implications of Community Involvement in 'Safeguarding'." In Laurajane Smith and Natsuko Akagawa (eds.), Intangible Heritage: 45-73. London: Routledge.

Brown, Jennifer S.H, 2007, "Rupert's Land, Nituskeenan, Our Land: Cree and English Naming and Claiming around the Dirty Sea." In Ted Binnema and Susan Neylan (eds.), New Histories for Old: Changing Perspectives on Canada's Native Pasts: 18-40. Vancouver: UBC Press.

Brown, Jennifer S.H. and Roger Roulette, 2005, "Waabitigweaa, the One Who Found the Anishinaabeg First." In Brian Swann (ed.), Algonquian Spirit: Contemporary Translations of the Algonquian Literatures of North America: 159-169. Lincoln: University of Nebraska Press.

Brown, Michael F., 2005, "Heritage Trouble: Recent Work on the Protection of Intangible Cultural Property." International Journal of Cultural Property 12: 40-61.

Cowan, Jane K., 2006, "Culture and Rights after Culture and Rights." American Anthropologist 108(1): 9-24.

Ellis, C. Douglas, 1995, Cree Legends and Narratives from the West Coast of James Bay. Winnipeg: University of Manitoba Press.

Faries, R. and W.A. Watkins, 1938, A Dictionary of the Cree Language.

Toronto: Anglican Book Centre.

Francis, Daniel and Toby Morantz, 1983, Partners in Furs: A History of the Fur Trade in Eastern James Bay 1600-1870. Kingston: McGill-Queen's University Press.

Geertz, Clifford, 1999, A Life of Learning. Charles Homer Haskins Lecture for 1999. American Council of Learned Societies Occasional Paper No. 45. James, Thomas, 1973 (1633), The Strange and Dangerous Voyage of Capt.

Thomas James in his Intended Discovery of a North West Passage into the South Sea wherein the Miseries Indured, both Going, Wintering and Returning, and the Rarities Observ'd Philosophical, Mathematical and Natural are Related... Toronto: Coles Publishing.

Lockhart, James, 1992, The Nahuas after the Conquest: A Social and Cultural History of the Indians of Central Mexico, Sixteenth through Eighteenth Centuries. Stanford: Stanford University Press. 
Long, John S., 1985, "Treaty No. 9 and Fur Trade Company Families: Northeastern Ontario's Halfbreeds, Indians, Petitioners and Metis." In Jacqueline Peterson and Jennifer S.H. Brown (eds.), The New Peoples: Being and Becoming Metis in North America: 137-162. Winnipeg: University of Manitoba Press.

Lytwyn, Victor P., 2002, Muskekowuck Athinuwick: Original People of the Great Swampy Land. Winnipeg: University of Manitoba Press.

Mushkegowuk Council, 2003, Press Kit: Rupert's Land Protection Pledge Lawsuit. Moose Factory: Mushkegowuk Council.

Pentland, David, 1981, "Synonymy." In John J. Honigmann, "West Main Cree" in June Helm (ed.), Subarctic. Handbook of North American Indians, vol. 6: 227-230. Washington: Smithsonian Institution.

Pentland, David, 1982, "French Loanwords in Cree." Kansas Working Papers in Linguistics 7: 105-117.

Phillips, Ruth B., 2006, "When Objects become Subjects: Aboriginal peoples, Intangible Heritage, and Canadian Museums." Paper presented at Seminar on the Politics of Intangible Cultural Heritage, Weatherhead Center for International Affairs, Harvard University.

Povinelli, Elizabeth, 2002, The Cunning of Recognition: Indigenous Alterities and the Making of Australian Multiculturalism. Durham: Duke University Press.

Preston, Richard J., 2002, Cree Narrative: Expressing the Personal Meaning of Events. $2^{\text {nd }}$ edition. Montreal: McGill-Queen's University Press.

Turgeon, Laurier, 2003, Patrimoines métissés: Contextes coloniaux et postcoloniaux. Paris: Editions de la Maison des sciences de l'homme; Quebec: Les Presses de L'Université Laval.

Turgeon, Laurier, 2006, "Prospectus for The Politics of Intangible Cultural Heritage." Seminar convened at the Weatherhead Center for International Affairs, Harvard University, spring 2006.

Wishart, Vernon R., 2006, What Lies behind the Picture? A Personal Journey into Cree Ancestry. Red Deer: Central Alberta Historical Society. 